\title{
SPECIA ALOGENĂ INVAZIVĂ CYDALIMA PERSPECTALIS ȘI MĂSURILE DE REGLARE A DENSITĂȚII POPULATIIONALE ÎN REPUBLICA MOLDOVA
}

\author{
Timuș Asea \\ Institutul de Zoologie, 2028 Chișinău, R. Moldova
}

https://doi.org/10.53937/9789975315975.62

Abstract: In the paper presents the allogeneic invasive species Cydalima perspectalis, first registered in the Republic of Moldova in 2017 in a park in the Chisinau capital. In 2018, investigations have been held to confirm its evolution in line with the climatic conditions in the area. According to species development in the second half of 2017 and the first half of 2018, it was found that the species is developing as in other countries in Europe: two generations and with the same aggressiveness. The paper describes the recommended fighting methods in countries where the species has developed in Europe, which are also valid for the republic.

Key words: Invasive species, Cydalima perspectalis, control methods

\section{Istoricul speciei Cydalima perspectalis în Europa și Republica Mol-} dova. Specia C. perspectalis este de origine est-asiatică (Japonia, China, Coreea, India) și face parte din fam. Crambidae, ord. Lepidoptera. În Europa a fost semnalată prima dată în Germania (2006), apoi în Elveţia și Olanda (2007), Franţa, Regatul Unit și Austria (2009). În anul 2011 a fost raportată în Ungaria, România și Turcia, iar în Republica Moldova - în 8.VIII.2017, de către autor în parcul MoldExpo (pe plantații de Buxus cu întreţinere dirijată) (Fig. 1).
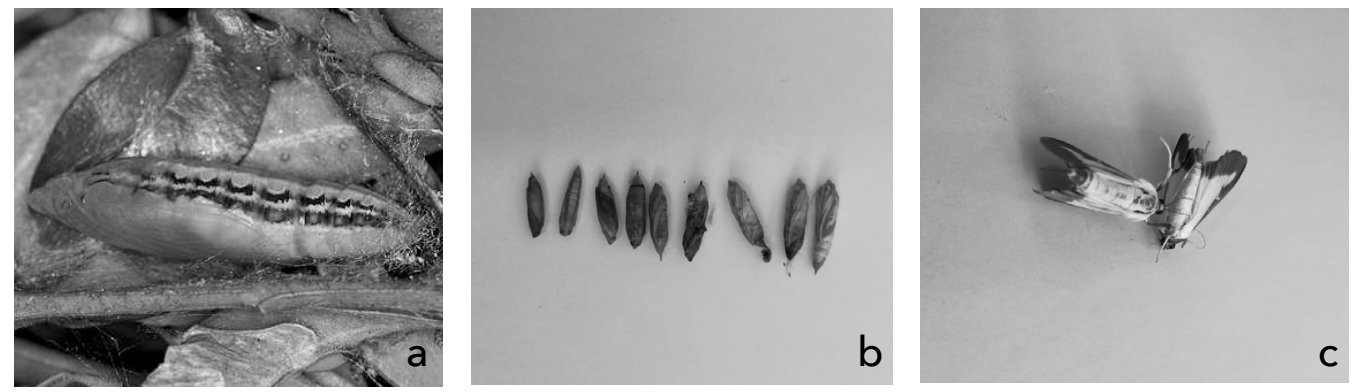

Figura 1. Stadiul de pupă (a-b) și imago (c), original. 
Migrarea și pătrunderea a avut prin 2 căi: (i) comerţul internaţional cu material săditor de Buxus în ghivece (oul, larvele din primele vârste, pupele din coconi), care se depistează greu în aparatul foliar; (ii) zbor natural al adulților.

Secvenţe din bioecologia speciei C. perspectalis în condiţiile din Republica Moldova. Insecta alogenă invazivă a fost depistată în parcul MoldExpo (primul focar), apoi observaţiile au continuat și în alte cartiere ale orașului Chișinău, inclusiv în campusul UASM. În anul 2018 investigaţiile au continuat, astfel s-a întocmit calendarul fenologic al speciei C. perspectalis în condiţiile din Republica Moldova (Fig. 2).

Stadiul dăunător și modul de dăunare. Larvele din primele vârste imediat după eclozare încep să se hrănească cu frunzele din partea de sus a lăstarului. În urma consumului limbului foliar, de la început apar "orificii", apoi pe parcurs de dezvoltare roade complet vârful frunzei spre pețiol. Acestea totalmente rod limbul foliar, lăsând intacte nervura centrală și uneori marginile exterioare, după care obțin aspect de "fire uscate de păr". Firele uscate și cu păienjenișul larvei formează un aspect caracteristic al speciei, inconfundabil cu altă insectă. Datorită dezvoltării larvei de foarte timpuriu în frunzișul buxusului și extrem de rapidă, poziționarea ei sub frunze și dimensiunile mici, se consideră ca specie agresivă și dificil de identificat.

În procesul de hrănire a larvei, are loc micșorarea suprafeţei limbului foliar și, respectiv, suprafaţa de frunză care participă la procesul de fotosinteză. Lăstarii stagnează în creștere și formarea altor muguri. Datorită acestui proces planta se usucă parţial sau total într-un timp foarte scurt.

Consecinţele atacului arboretelui de Buxus: aspectul estetic al plantei este redus (rosături de frunze, uscare de ramuri și plante, excremente, frunziș uscat în interiorul tufei, acumulare de gunoaie biologice, care duc până la urmă provocarea unor boli); gardurile verzi din buxus arată neadecvat și necesită lucrări suplimentare; parcurile și scuarele pierd din imaginea atractivă și produce un disconfort pentru vizitatori; atacul insistent 
și mai mulţi ani la rând provoacă defrișarea plantațiilor de buxus (proces deja realizat în parcul MoldExpo în primăvara anului 2018); defrișarea, replantarea, formarea și întreţinerea altor specii de plante sunt costisitoare.

\begin{tabular}{|c|c|c|c|c|c|c|c|c|c|c|c|c|c|c|c|c|c|c|c|c|c|}
\hline & $\frac{\frac{0}{\bar{L}}}{\frac{0}{\alpha}}$ & & & $\sum^{\bar{\sigma}}$ & & & & & & & & & & & & & & & 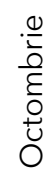 & & 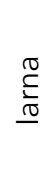 \\
\hline I & II & III & I & II & III & I & II & III & I & II & III & I & II & III & I & II & III & I & II & III & \\
\hline L2 & L3 & L4 & L5 & & & & & & & & & & & & & & & & & & \\
\hline & & & 0 & 0 & 0 & 0 & 0 & & en & aţi & 1,5 & uni & & & & & & & & & \\
\hline & & & $o p$ & upă & 10 & 42 & & & & & & & & & & & & & & & \\
\hline & & & & + & + & + & + & + & + & + & + & & & & & & & & & & \\
\hline Ger & hera & ia 1 & de & ară & & & & & & & & & & & & & & & & & \\
\hline & & & & & * & * & * & * & * & * & $\star$ & & & & & & & & & & \\
\hline & & & & & & $L$ & L & $L$ & $\mathrm{~L}$ & L & L & & 15 & ârs & & & & & & & \\
\hline & & & & & & & & & 0 & 0 & 0 & 0 & & & & & & & & & \\
\hline & & & & & & & & & & + & + & + & + & + & & & & & & & \\
\hline & & & & & & & & & & & 110 & arr & $-p$ & mă & & & & & & & \\
\hline & & & & & & & & & & & & * & * & * & & & & & & & \\
\hline & & & & & & & & & & & & & L & L & $\mathrm{L}$ & $\mathrm{L}$ & L & $\mathrm{L}$ & L2 & L2 & L2 \\
\hline & & & & & & & & & & & & & & & & & & & & & \\
\hline
\end{tabular}

Figura 2. Calendarul fenologic pentru omida păroasă a buxusului:

Legenda: + - imago, * - oul; L - larva (2 vârsta); 0 - pupa (original)

Măsurile de combatere. Pentru combaterea efectivă este necesar ca defoliatorul să fie monitorizat permanent, chiar dacă nu au fost observate defolieri. La depistare, măsurile de combatere se aplică de la începutul până la încheierea primăverii. Măsurile de combatere se împart în grupe distinctive: 1) profilactice - material săditor liber de insectă și agenţi patogeni; 2) igiena fitosanitară - întreţinerea adecvată a plantelor 
de buxus (tăierile necesare, inclusiv tăierile și distrugerea parţilor infestate de dăunător; irigarea cu un jet puternic de apă sau folosirea unui aspirator de recoltare a omizilor; pe suprafeţele mici strivirea mecanică a ouălor și larvelor), fiindcă formează garduri vii sau plante decorative; 3) curative - aplicarea de preparate chimice direcţionate împotriva larvelor din primele vârste (primavara când acestea devin active, și/sau împotriva larvelor, eclozate din ouăle, depuse de femelele apărute mai târziu); 4) biologice - capcane feromonale pentru captarea masculilor adulţi; aplicarea biopreparatul pe baza de Bacillus thuringiensis serovar împotriva larvelor din primele vârste (recomandare europeană).

\section{CONCLUZII ȘI RECOMANDĂRI}

Din investigarea entomofaunei care se dezvoltă pe arbustul decorativ Buxus sempervirens în anii 2017-2018 concluzionăm: arbustul decorativ este o specie alogenă pentru Europa, inclusiv Republica Moldova. Insecta monofagă C. perspectalia este o molie, la fel, nouă pentru entomofauna republicii, fiind înregistrată în 2017 în parcul de la MoldExpo.

Specia iernează în stadiul de larvă incomplet dezvoltată în interiorul arbustului de buxus, printre ramuri și resturi vegetale, ţesând preventiv un plasă mătăsoasă rară. La stabilirea to ${ }^{\circ}$ optime de dezvoltare (de la $5^{\circ}$ ), larvele încep intensiv hrănirea. Specia dezvoltă 2 generaţii pe an, una dintre care se divide în 3 sezoane: sfârșit de vară, toamnă și primăvară.

Specia C. perspectalia este foarte agresivă și consecineţele atacului aparatului foliar al plantei de buxus este devastator, până la uscarea și moartea plantei, iar ca dovadă în parcul de la MoldExpo a început defrișarea arboretelui cu forme estetice.

Recomandări. Metoda chimică de combatere a insectelor dăunătoare buxusului se recomandă de evitat cât posibil, fiindcă pe această plantă se dezvoltă o mare gamă de alte nevertebrate și consecinţele sunt inevitabile în distrugerea lanţurilor trofice: cinci specii polenizatoare (Vespula germanica, Apis melifera și trei specii de lepidoptere); cinci entomofagi 
(3 coccinelide, 1 formicid și 1 forficulid), cinci polifage (Tettigonia viridisima și patru ploșniţe).

Defrișarea gardurilor vii în urma atacului de C. perspectalis se recomandă de evitat, fiindcă planta de buxus are proprietăţi de regenerare. În contextul salvării plantelor este necesar insistent și abundent de irigat arbustul sau gardul verde din buxus, pentru a provoca trezirea mugurilor dorminzi și refacerea apartului foliar. Experienţa respectivă a avut succes în multe ţări, spre exemplu și în România.

Studiile au fost realizate în cadrul proiectului instituțional fundamental 15.817.02.12F.

\section{BIBLIOGRAFIE}

1. Gabor Vetek, Asea Timuș, Mariam Chubinishvili, Gayane Avagzan, Vardan Torchan, Zsuzsanna Hajdu, Andrea Veres, Avetik Nersisyan. Integrated pest management of major pests and diseases in estern Europe and the Caucausus. Food and Agriculture Organization of the United Nations. Budapest, 2017, 98 p. (inclusiv în română și rusă)

2. Geza Nagy, Vetek Gabor, Daunatori și agenti patogeni în gradină. Ediţia a 2-a, 2016.

3. Timuș Asea, Nina Școlnîi. Coccinelide frecvente în biotopurile antropizate. Lucrările Conferinţei știinţifice a tineretului studios dedicată Zilei Internaţionale a Studenţilor cu participare internaţională "Homo sapiens în raporturile dintre sistemele naturale și factorii de mediu". Chișinău, 2015, p. 82-85.

4. Timuș Asea, Stahi Nadejda. Study contributions regarding forms of Harmonia axiridis in the Republic of Moldova. În: Culegerile de lucrări știinţifice a Institutului de Zoologie, AȘM, 2013, vol. 8, p. 182-184.

5. Timuș Asea, Stahi Nadejda. The acclimatization and trophic spectrum of Harmonia axiridis in the Republic of Moldova. În: Culegerile de lucrări știinţifice a Institutului de Zoologie, AȘM, 2013, vol. 8, p. 180-182.

6. Timuș Asea, Toderaș I., Croitoru N. Entomofauna alogenă invazivă din Republica Moldova (fișe fitosanitare entomologice). Tipografia "Print Caro", Chișinău, 2016, 210 p.

7. Timuș Asea. Entomofauna invazivă recentă din peisajul cultural al capitalei Republicii Moldova. Tezele conf. internaţionale. Chișinău: Ministerul Mediul din Republica Moldova, 2015, p. 169-172. 